\title{
РЕТРОСПЕКТИВНИЙ АНАЛІЗ ЕПІДСИТУАЦІї ЩОДО ТУБЕРКУЛЬОЗУ НА ТЕРИТОРІЇ ТЕРНОПІЛЬСЬКОЇ ОБЛАСТІ ЗА 2010-2014 РОКИ
}

\author{
Головне управління Держсанепідслужби у Тернопільській області, \\ Тернопільський обласний лабораторний центр Держсанепідслужби України
}

Протягом останніх років епідемічна ситуація щодо туберкульозу на території області, незважаючи на зниження показників захворюваності та смертності, залишається напруженою. Домогтися зниження розповсюдження туберкульозу на території області можна за умови активного реагування на проблему, покращення фрінансування, впровадження сучасних методів діагностики та лікування, організації ефективних профілактичних і протиепідемічних заходів в осередках.

Ключові слова: туберкульоз, епідситуація, ретроспективний аналіз, Тернопільська область.

В умовах епідемії туберкульозу, визнаної на світовому та загальнодержавному рівні, із врахуванням впливу як медичних, так і соціальних чинників на суспільство, туберкульоз залишається актуальною проблемою сьогодення.

За міжнародними критеріями Всесвітньої організації охорони здоров'я, епідемія туберкульозу на визначеній території оголошується тоді, коли рівень захворюваності вище 30 випадків на 100 тисяч населення.

Протягом останніх років епідемічна ситуація щодо туберкульозу на території області, незважаючи на зниження показників захворюваності та смертності, залишається напруженою. За останнє десятиріччя показник захворюваності на туберкульоз (вперше виявлені випадки) серед населення області коливається в межах 55-45 випадків на 100 тис. населення, смертності - 14-6 вип. на 100 тис. населення. Вище зазначені показники є доказовими аргументами існування епідемії туберкульозу в області.

На кожній окремій адміністративній території області запроваджено щоденну звітність стосовно реєстрації інорекційної захворюваності та результатів проведеного епідрозслідування. В цілому щодня реєструється близько 40 термінових повідомлень про випадки інфекційних захворювань, насторожує той фракт, що з них 4-5 випадків туберкульозу. Тобто, при щоденній реєстрації частка випадків туберкульозу в структурі загальної інсрекційної захворюваності становить близько $12 \%$.За результатами щомісячної статистичної звітності, питома вага захворюваності на туберкульоз (органи дихання) в загальній структурі інфрекційних захворювань без грипу та ГРВІ коливається в межах 13-15\%.

Для оцінки епідситуації щодо туберкульозу слід, окрім традиційної статистики (захворюваність, смертність), використовувати такі об'єктивні показники:

зростання кількості бацилярних і деструктивних (задавнених) фрорм туберкульозу (кожен 2-й хворий із бактеріовиділенням, кожен 4-й хворий виявлений на пізніх стадіях захворювання) - потенційна небезпека для оточуючих;

щорічна реєстрація випадків серед дітей, підлітків, контактних осіб в осередках туберкульозу, декретованого контингенту населення, медиків;

суттєва реєстрація випадків рецидивів захворювання після пройденого курсу лікування, мультирезистентного туберкульозу, ко-інфекції (туберкульоз, ВІЛ-інфекція/СНІД).

За результатами оцінки основних епідеміологічних критеріїв, висновок щодо епідситуації з туберкульозу в області такий.

Реєстрація значної кількості випадків туберкульозу із бактеріовиділенням_(МБТ+) (48-59 \%) та деструкцією (задавнені форми) (40-47 \%) свідчить про недостатню роботу лікувальної мережі в напрямку активного виявлення хворих на початкових стадіях захворювання. Слід зазначити, що за добу хворий з активною формою туберкульозу виділяє у довкілля близько 15-20 млн мікобактерій туберкульозу і протягом року може інфрікувати 10-15 осіб. Зростання частки бактеріовиділювачів підтверджує наявність значної кількості джерел інфекції.

Протягом останніх років продовжують реєструватись випадки серед контактних осіб у домашніх осередках (від 8 до 12 випадків). Захворюваність серед контактних відображає якість організації медичного спостереження, своєчасність лабораторної діагностики.

Реєстрація випадків захворювань на туберкульоз серед обов'язкового (декретованого) контингенту населення (від 24 до 33 випадків) свідчить про недостатню роботу в напрямку активного виявлення хворих при проведенні профрілактичних медичних оглядів. Щорічно на 


\section{КОРОТКІ ПОВІДОМЛЕННЯ}

кожній адмінтериторії лікувальною мережею здійснюється планування фрлюорографрічних обстежень відповідно до чисельності населення та в розрізі передбачуваних контингентів. Протягом останніх років відсоток виконання плану ФГ-обстежень досить високий - 94-96 \%, однак питома вага активно виявлених хворих на туберкульоз коливається в межах 0,05 \%

Насторожує постійна реєстрація випадків серед працівників лікувально-профілактичних закладів області (9-12 випадків). У структурі захворюваності зберігається тенденція: перше місце посідає молодший медичний персонал, друге - середній медперсонал, третє - лікарі. Окремо слід виділити реєстрацію захворюваності серед працівників протитуберкульозних закладів (1-5 випадків), умови праці яких пов'язані з високим ризиком інфрікування (контакт $з$ мікобактеріями туберкульозу). Реєстрація випадків туберкульозу серед медичних працівників $€$ своєрідним показником організації роботи як загальної лікувальної мережі, так і протитуберкульозних закладів.

Суттєва реєстрація випадків рецидивів захворювання $\epsilon$ індикатором якості надання медичної допомоги та ефективності призначеного курсу лікування. Щорічно кількість рецидивів захворювання коливається від 84 до 110 випадків (інтенсивний показник - 7,7-10,2 вип. на 100 тис. населення)

Окремої звітності потребує реєстрація випадків мультирезистентного туберкульозу (нечутливих до протитуберкульозних препаратів) - реальну ситуацію неможливо оцінити у зв'язку з відсутністю офріційної статистики. Серед причин неефективності лікування виділяють: пізнє звернення, порушення режиму лікування, супутню патологію (алкоголізм, наркоманія), перебування в закладах пенітеціарної системи.

Залишається проблемною реєстрація поєднаної патології - ко-інфекція (туберкульоз + ВІЛ/СНІД). Протягом останніх років кількість таких випадків коливається від 7 до 15 (інтенсивний показник - 0,6-1,4 вип. на 100 тис. населення). Наявність ВІЛ-інсрекції є потужним фрактором впливу на розвиток активного туберкульозу у носіїв латентної інфрекції, підвищує ризик рецидивів туберкульозу. На сьогодні (згідно статистики) 30 \% осіб, що живуть з ВІЛ-інфекцією/ СНІДом, хворіють на туберкульоз, а 40 \% - помирають від цієї патології.

В області залишається високим рівень смертності від всіх фрорм туберкульозу - 6-10 вип. на 100 тисяч населення.

Щорічна реєстрація випадків туберкульозу серед дітей та підлітків $€$ негативною прогностичною ознакою епідблагополуччя території. Протягом останніх років захворюваність всіма активними фрормами туберкульозу серед дітей знаходиться в межах від 0,6 до 5,3 вип. на 100 тис. населення, серед підлітків - 11,-33,8 вип. на 100 тис. населення. В більшості випадків первинне інфікування дитячого організму проявляється у вигляді позалегеневого туберкульозу, без залучення в інфекційний процес специфічних органів локалізації мікобактерій. Однак загрозливим є те, що серед підлітків реєструються випадки туберкульозу легень, що супроводжуються бактеріовиділенням та деструкцією.

Аналіз даних епідрозслідування свідчить, що хворіють на туберкульоз в основному діти з груп ризику, а саме: невакциновані в пологових стаціонарах у зв'язку з наявністю протипоказань, контактні з хворими членами сім"ї у домашніх осередках, попередньо інфріковані на фоні зниження резистентності організму (динамічні результати туберкулінодіагностики).

Одним з найесрективніших методів раннього виявлення як первинного інфрікування, так і захворювання на початкових стадіях залишається щорічна туберкулінодіагностика серед дітей.

На території області організовано проведення туберкулінодіагностики дитячого населення віком від 1 до 17 років (з 2015 р. - 34 до 14 років), очищений туберкулін закупляється за кошти місцевих бюджетів. Щорічно відсоток охоплення туберкулінодіагностикою дитячого населення коливався в межах 70 \%, однак у 2013 р. - 24,6 \%, 2014 р. - 16,4 \% (недостатнє забезпечення туберкуліном).

Виконання запланованих обсягів проб Манту залежить від ефективності роботи лікувальної мережі щодо залучення контингентів, які підлягають обстеженню, результативності техніки введення та прочитання реакцій, своєчасності фрінансування на місцях.

Профрілактика туберкульозу за допомогою вакцинації $€$ основним способом боротьби з цим небезпечним захворюванням. Основна мета - запобігання захворюванню і його поширенню у дітей. Імунізація як метод специфічної профрілактики серед дитячого населення забезпечує у $80 \%$ випадків стійкий імунітет (захист від розвитку всіх фрорм туберкульозу).

В області середній відсоток вакцинації дітей в пологових стаціонарах протягом 2010-2013 рр. становить 84,4 \%. У 2014 р. засріксовано вкрай низький відсоток імунізації новонароджених - 22,5 \% (відсутність вакцини БЦЖ).

У зв'язку з недостатнім забезпеченням імунобіологічними препаратами (туберкулін, вакцина БЦЖ) протягом останніх кількох років, ситуація щодо стану профрілактики туберкульозу в області викликає занепокоєння, адже на фроні зниження кількості захищених (імунізованих) створюються сприятливі умови для поширення збудника в зовнішньому середовищі, в результаті - розширення резервуару туберкульозної інфекції.

Враховуючи вище викладене, зазначаємо, що Держсанепідслужбою області здійснюється об'єктивна оцінка епідситуації щодо туберкульозу на кожній адміністративній території області із врахуванням не тільки статистичних показників, а й ретроспективний аналіз динаміки захворюваності, хворобливості, вогнищевості (табл. 1). 


\section{КОРОТКІ ПОВІДОМЛЕННЯ}

Таблиця 1

Ретроспективна оцінка епідситуації в Тернопільській області щодо туберкульозу за основними показниками (2010-2014рр.)

\begin{tabular}{|c|c|c|c|c|c|c|}
\hline Група & Показник & 2010 & 2011 & 2012 & 2013 & 2014 \\
\hline \multirow[t]{2}{*}{ Захворюваність (всі активні форми) } & Абс. & 591 & 580 & 546 & 511 & 486 \\
\hline & Інт. на 100 тис. & 54,4 & 53,4 & 50,5 & 47,6 & 45,2 \\
\hline \multirow[t]{3}{*}{ МБТ + (бактеріовиділення) } & Абс. & 244 & 260 & 233 & 241 & 258 \\
\hline & Інт. на 100 тис. & 22,5 & 23,9 & 21,6 & 22,4 & 24,0 \\
\hline & $\%$ & 48,5 & 52,1 & 48,8 & 53,4 & 59,9 \\
\hline \multirow[t]{3}{*}{ Деструкція (задавнені фрорми) } & Абс. & 241 & 235 & 225 & 181 & 177 \\
\hline & Інт. на 100 тис. & 22,2 & 21,6 & 20,8 & 16,9 & 16,5 \\
\hline & $\%$ & 47,9 & 47,1 & 47,2 & 40,1 & 41,1 \\
\hline \multirow[t]{2}{*}{ Захворюваність серед дітей } & Абс. & 6 & 7 & 9 & 8 & 1 \\
\hline & Інт. на 100 тис. & 3,5 & 4,1 & 5,3 & 4,7 & 0,6 \\
\hline \multirow[t]{2}{*}{ Захворюваність серед підлітків } & Абс. & 5 & 13 & 14 & 6 & 12 \\
\hline & Інт. на 100 тис. & 11,6 & 30,0 & 33,8 & 14,5 & 31,2 \\
\hline \multirow[t]{2}{*}{ Хворобливість } & Абс. & 1602 & 1089 & 1046 & 817 & 799 \\
\hline & Інт. на 100 тис. & 147,6 & 100,8 & 97,1 & 76,1 & 74,4 \\
\hline \multirow[t]{2}{*}{ Рецидиви } & Абс. & 84 & 84 & 105 & 91 & 110 \\
\hline & Інт. на 100 тис. & 7,7 & 7,7 & 9,7 & 8,4 & 10,2 \\
\hline \multirow[t]{2}{*}{ Ко-інфекція (+ ВІЛ/СНІД) } & Абс. & 15 & 7 & 13 & 14 & 9 \\
\hline & Інт. на 100 тис. & 1,4 & 0,6 & 1,2 & 1,3 & 0,84 \\
\hline \multirow[t]{2}{*}{ Смертність } & Абс. & 109 & 102 & 83 & 65 & 89 \\
\hline & Інт. на 100 тис. & 10,0 & 9,4 & 7,7 & 6,2 & 8,3 \\
\hline
\end{tabular}

Позитивна динаміка щодо зниження поширення туберкульозу на території області можлива за умови активного реагування на проблему, покращення фрінансування, впровадження сучасних методів діагностики та лікування, організації ефективних профілактичних і протиепідемічних заходів в осередках.

\section{RETROSPECTIVE ANALYSIS EPIDEMIOLOGICAL SITUATION FOR TUBERCULOSIS IN TERNOPIL REGION DURING 2010-2014}

V.O. Panychev, M.M. Pavelyeva, I.V. Kulachkovska, S.V. Matsipura, N.I. Hodovana

SUMMARY. In recent years the epidemic situation with tuberculosis in the region, despite the decrease morbidity and mortality remains tense. To reduce the spread of tuberculosis in the region can be provided an active response to the issue, better funding, introduction of modern methods of diagnosis and treatment, organization of effective preventive and anti-epidemic measures.

Key words: tuberculosis, epidsytuation, retrospective analysis, Ternopil region.

Отримано 2.03.2015 р. 